\title{
Designing a food supply chain network under public-private community partnership on traditional Indonesia markets
}

\author{
Neneng Siti Maryam ${ }^{a^{*}}$, Heru Nurasa $^{\mathrm{b}}$, Muhammad Benny Alexandri ${ }^{\mathrm{b}}$ and Yogi Suprayogi Sugandi ${ }^{\mathrm{b}}$
}

${ }^{a}$ Faculty Post-Graduate Student in Public Administration Faculty of Social and Politic Sciences, Universitas Padjadjaran Bandung, Indonesia ${ }^{b}$ Faculty of Social and Politic Sciences, Universitas Padjadjaran Bandung, Indonesia

\section{H R O N I C L E}

\section{Article history:}

Received March 12, 2021

Received in revised format May 8 , 2021

Accepted August 122021

Available online

August 122021

Keywords:

Food supply chain

Public-Private-Community

Partnership

Traditional market

\section{A B S T R A C T}

\begin{abstract}
This study examines the effect of the performance of traders in the partnership relationship between the government, the private sector, and the community which is very necessary to build a food supply chain network in order to provide stimulation for the supporting factors and reduce the inhibiting factors for the success of the merchant's business, increase profits, and maintain food availability in traditional markets. This research was conducted at Andir Market, Bandung City, Indonesia. The research sample consisted of 100 Andir market traders. The research method used was a quantitative method with survey research that uses a questionnaire as the main instrument in data collection. The results of the analysis and discussion of the researchers have identified factors that can be used to strengthen the food supply chain network in the Public-Private-Community Partnership in traditional markets, namely management, empowerment, physical market conditions, and competitive strategies. Simultaneously, the four traders' performance factors have a significant effect on the food supply chain network with an R-square value of $0.658(65.8 \%)$ with tcount greater than 1.96 or $(3.817>1.96)$. This means that if the changes that occur are good in the performance of traders, the food supply chain network in traditional markets will also be good, while the remaining $0.342(34.2 \%)$ is explained by factors other than these variables. The expected implication is that the success of the supply chain network that is built due to strong interactions within the Public-Private-Community Partnership and other supply chain actors is able to face challenges during and after the pandemic. So that the quality of traditional market products, especially products that are quickly damaged or rotten, can be superior and well guaranteed for the food needs of people throughout Indonesia.
\end{abstract}

(C) 2021 Growing Science Ltd. All rights reserved.

\section{Introduction}

Traditional markets are one of the supporting facilities whose existence can support the needs of the community. Unfortunately, traditional markets often fail because they do not have a social aspect and only prioritize physical and economic arrangements (Febrianty, 2013; Widiastuti, Paturusi, \& Dwijendra, 2017; Ardhiansyah \& Mahendarto, 2020). In fact, in the midst of the current Covid-19 Pandemic (Basrowi, Utami, Ali, \& Salleh, 2021), it is very important to design a supply chain network in traditional markets to maintain the quality of food products throughout the supply chain which is expected to increase market attractiveness so that they are able to compete dynamically, thereby increasing market activity and improving the living standards of traders (Chenarides, Manfredo, \& Richards, 2021). Traditional markets are hereditary heritages that have been passed down for a long time and have cultural and customary values, so they need to be maintained and preserved by all levels of society (Hill, 1966). Traditional markets have natural competitive advantages that are not directly owned by modern markets, namely the existence of a bargaining system that shows the closeness and intimacy between the seller and the buyer (Nelwan \& Rumokoy, 2017). There are also other advantages as expressed by several researchers explaining that cultural factors and marketing activities cause consumer equity to shop at traditional markets, can socialize with sellers,

* Corresponding author

E-mail address: nenengunpad@gmail.com (N. Siti Maryam)

(c) 2021 Growing Science Ltd. All rights reserved.

doi: $10.5267 /$ j.uscm.2021.8.005 
produce fresher goods, and have the opportunity to bargain prices (Wang, Ko, Woodside, \& Yu, 2021). Along with the development of the digital era 4.0, traditional markets have begun to attract less attention from visitors who are starting to switch to modern markets. Traditional markets must undergo a digital transformation and focus on delivery applications (Hong \& Yang, 2021). For traditional markets that are adaptive and sustainable, socio-cultural values, physical aspects, and economics are important holistic concerns (Misirlisoy, 2020). This is due to the limited level of service and the absence of magnets in traditional markets that can attract visitors' attention. In addition, the inherent bad stigma about product quality in traditional markets is increasingly clouding consumer perceptions, often resulting in some visitors looking for alternative shopping places (Najib \& Sosianika, 2017). In fact, the majority of visitors belonging to the upper middle-income segment tend to switch to modern markets, such as supermarkets (supermarkets and minimarkets) which are usually more concerned with product quality, cleanliness, and comfort, as the basis for consideration of switching places to shop (Kurniawan, Lubis, \& Simanullang, 2020).

In Indonesia, the traditional market in Bandung City is managed by the government in collaboration with the private sector. Therefore, this traditional market should have a good food supply chain because of the Public-Private-Community Partnership. The management of the market owned by the Bandung City Government is carried out by the Regional Company of the Bandung City Market (PD Pasar Bermartabat), as one of the regional apparatuses that have the task of assisting the mayor. Currently, the number of traditional markets in the city of Bandung is 37 markets spread across various areas in the city of Bandung. Of the 37 markets, eight of them are managed by third parties with a cooperative system, namely Cicadas Market (now Bandung Trade Mall), New Market (now Pasar Baru Trade Center), Dewi Sartika Market (now ITC Kebon Kelapa), Andir Market (Andir Trade). Centre), Ciroyom Market (now Dignified Ciroyom), Balubur Market (Baltos), Banceuy and Karapitan (Paskarina, Mariana, \& Atmoko, 2007). Based on preliminary observations made by researchers, of the many traditional markets in Bandung, the research locus is Pasar Andir, with the reasons; 1) Andir Market is one of three markets (besides Pasar Baru and Pasar Kosambi) which have historical value and play an important role in the progress and welfare of the people of Bandung City, and their management has been in collaboration with third parties; 2) In its management by the private sector, it creates problems, both with traders and with the government. Another problem arises, from the many traditional markets, there are some supply chain traditional markets that are still relatively weak.

The transportation of agricultural products in traditional markets has been much disrupted. This is exacerbated by the limited capacity of cold storage facilities in the product area which causes the loss of perishable food (Yuanita, 2020). To become a traditional market that still exists and is successful, the development of Andir Market must be able to accommodate daily market activities, culinary activities, and entertainment activities. Andir traditional market plays an important role in driving the economy of the people of Bandung, apart from being the estuary of the people's products, the market also functions as a place to work which is very meaningful for the community (Paskarina et al., 2007).

In addition, changes in consumption patterns will also have a major impact on future food security. The strategy needed is useful for maintaining customers and their business existence, building plans, changing the image and distinctiveness that is able to meet the needs and demands of consumers as is done by the modern market. The latest study states that the role of Traders as actors of sustainability governance in the food supply chain is very important to make the strategy work well and even must be able to synergize every element or party involved in fostering and empowering traditional markets (Grabs \& Carodenuto, 2021). This is the novelty of research investigating the effect of traders' performance as actors of sustainable governance in the food supply chain, where previous research is rarely found revealing the involvement of traders to investigate the factors that affect the food supply chain. Recent studies investigate the same themes but relate to the conceptual framework and government policies (Huang, Yang, \& Wang, 2021); safety, risk, and product quality perspectives (Kumar, Mangla, Kumar, \& Song, 2021); and the role of technology (Alfian et al., 2020; Zhu \& Krikke, 2020; Shahbazi \& Byun, 2021). This case study is the background of the need to investigate the factors that can strengthen the Food Supply Chain Network in the Public-Private-Community Partnership in Traditional Markets in Indonesia.

\section{Theoreticalreview}

\subsection{Food Supply Chain}

The term supply chain is understood as the integration of key business processes from end users through original suppliers that provide products, services, and information that add value to customers and other stakeholders (Mukhsin \& Suryanto, 2021). In simple terms, the supply chain is a series of goods/physical flows, information, and processes used to deliver products or services from source locations (suppliers) to destination locations (customers or buyers) (Lambert, Cooper, \& Pagh, 1998). According to Zuurbier (1996) the types of food supply chains are divided into two, namely; a) supply chain of fresh food products; and b) the supply chain of processed food products. The characteristic of the food supply chain lies in its continuous and significant changes in the quality of food products throughout the supply chain until the endpoint where the product is consumed. The food supply chain moves continuously from the producer to go through the production and processing process, through distribution, retail to the consumer. Especially for food products that are easily damaged or spoiled, the risk of generating waste and losses in each supply chain has a very high potential which has an impact on the low profits and quality of food products (Kumar et al., 2021). The study states that the success of the food supply chain is highly 
dependent on strong and effective interactions between ingredient vendors, contract packaging providers, repackers, comanufacturers, intermediary traders, and other suppliers involved in the supply chain. In the food supply chain, all supply chain stakeholders are responsible for preventing product contamination that can cause the product to become hazardous to (Kumar et al., 2021).

\section{Public-Private-Community Partnership}

Public-Private-Community Partnership (PPCP) is a synergistic operational model that aims to achieve sustainable development in which the three parties jointly develop business units/services that are mutually beneficial and provide the maximum benefit to the wider community. The ten success factors of PPCP consist of a plan/vision mission, commitment to cooperation and trust, willingness to compromise and collaborate, mutual respect, community outreach, political support, expert advice and review, awareness of risks, and clear roles and responsibilities of each stakeholder (Jacobson \& Ok, 2008; Adnyana, Anwar, Soemitro, \& Utomo, 2015). Community involvement in public-private partnerships must be adapted to technology, especially those that focus on environmental health issues (Zahur, 2007). Within this framework, partnerships can take various forms, but roles and responsibilities must be clearly defined. Generally, each sector pursues not only common but also personal goals. The role of the private sector is classified as capable of providing political and economic benefits in the long term with balanced inclusiveness between producer and consumer chains. The public sector will benefit from additional resources, and investment value as well as guaranteed participation and ownership of the parties involved. Meanwhile, the community will benefit by acquiring new skills, knowledge and technology (Skietrys, Raipa, \& Bartkus, 2008). The literature reveals that this cooperative model can be the best approach to achieve inclusive growth and equitable and sustainable development. PCPP encourages formulation and facilitates the creation of mutual understanding, agreement, and support in designing long-term development (Kolzow, 1994).

\subsection{Traditional Market}

Traditional markets are markets that are built and managed by the government or private sector where bargaining and trading activities occur between sellers and buyers directly. Traditional markets generally sell basic needs and are small-scale (Hill, 1966). Its functions are as a source of regional levies, a place for exchanging goods, a center for community economic development, a regional money circulation center, and employment opportunities. In this case, service quality factors and consumer identification play an important role in repurchasing in traditional markets (Rahadi, 2012). The traditional market power consists of three kinds, namely; a) in their activities, sellers and buyers can conduct transactions directly; b) the existence of a process of social interaction that affects decisions and satisfaction between buyers and sellers; and c) in terms of location, traditional markets are always close to residential areas so that they are more efficient in time and energy (Kaplow, 1982). Traditional market risk management focuses on the distribution of changes in portfolio value resulting from changes. Therefore, market risk has traditionally been assessed on the assumption of an ideal market. More deeply, the liquidity effect can result in underestimating market risk in traditional markets especially in developing countries (Bangia, Diebold, Schuermann, \& Stroughair, 2001).

\section{Research methods}

To obtain empirical data and information, this research uses quantitative methods by means of surveys. Quantitative data was collected through questionnaires which were randomly distributed to 100 Andir market traders. Quantitative analysis is used to determine the effect of Andir Market management on the performance of traders through empowerment, market physical conditions and competitive strategies of traders, as well as other data such as age of traders, duration of trading, trading hours, gender and education level. Quantitative data analysis in this study using descriptive analysis and testing the research model using SEM-PLS Smart-PLS. Variable X data is data related to management, empowerment, market physical condition and competitive strategy (exogenous variable), while data on Y variable is data related to trader performance (endogenous variable). Testing is done through the validity and reliability of the instrument and the model fit test. The use of this test is to obtain the value of the effect of each exogenous variable on the endogenous variable. The purpose of this design is to explain the results of quantitative data obtained from the variables of management, empowerment, market physical conditions, competitive strategies, and market traders' performance.

\subsection{Data Collection Technique}

Primary data is data obtained from research informants who have been selected based on the coverage area of this study. Primary data obtained through observation and questionnaires. Observation is used to record primary data in the form of certain social events or situations at the research location related to the research focus. The instrument used is in the form of field notes. While the questionnaire was used to obtain data on the factors that affect the performance of Andir Market traders. Secondary data, is data obtained through literature studies and documentation. Literature study by conducting a literature review by reading and studying literature, books related to research topics, plus searching online data using the internet related to the management of the Andir Market, including data on the existing condition of the Andir Market. It aims to seek the truth and theories or opinions of others, in addition to the opinion of the researcher, and also to strengthen the opinion of the researcher in this study. In this study, the documents used as references are in the form of manuscripts, official documents, articles and photographs related to 
the research topic. With documentation can help researchers determine the suitability of the data with the reality in the field. These data include an overview of the Andir Market, Andir Market Facilities and Infrastructure, and other data that supports the research topic.

\section{Measurement Model}

The first step is to examine the effect of the performance of traders in the partnership relationship between the government, the private sector, and the community in designing the food supply chain, starting with the data processing process by collecting data through a questionnaire survey distributed to 100 traders. The questionnaire aims to determine the effect of management, empowerment, market physical conditions and competitive strategies on the performance of traders. Analysis of the data in this study using descriptive analysis and testing the research model using SEM-PLS Smart-PLS. Variable X data is data related to management, empowerment, market physical condition and competitive strategy (exogenous variable), while data on $\mathrm{Y}$ variable is data related to trader performance (endogenous variable).

\subsection{Validity and Reliability Measurement Model}

The validity test of the management questionnaire was carried out on statement items showing the results where all statement items were for the management variable $\left(\mathrm{X}_{1}\right)$, empowerment variable $\left(\mathrm{X}_{2}\right)$, competitive strategy variable $\left(\mathrm{X}_{3}\right)$ market physical condition variable $\left(\mathrm{X}_{4}\right)$, and trader performance variable $(\mathrm{Y})$ is valid because the value of rcount is greater than the critical value of 0.30 . This indicates that all statements made on the management variable are valid and considered feasible and can be used for research purposes. Reliability testing is carried out on statement items that are included in the valid category. As for the results of the reliability test based on the Cronbach Alpha formula, the reliability value of the statement items on the questionnaire for each variable being studied is greater than 0.70 . These results indicate that the questionnaire items on each variable are reliable to measure their respective variables and can be used for research.).

Table 1

Data Reliability Test Results

\begin{tabular}{|c|c|c|c|}
\hline \multirow{2}{*}{ Variable } & \multicolumn{3}{|c|}{ Reliability } \\
\hline & R Critical & Critical Point & Conclusion \\
\hline Market Management_( $\left.\mathrm{X}_{1}\right)$ & 0.961 & 0.7 & Reliable \\
\hline Empowerment_( $\left.\mathrm{X}_{2}\right)$ & 0.946 & 0.7 & Reliable \\
\hline Market Physical Condition_( $\left.\mathrm{X}_{3}\right)$ & 0.968 & 0.7 & Reliable \\
\hline Competitive strategy_ $\left(\mathrm{X}_{4}\right)$ & 0.936 & 0.7 & Reliable \\
\hline Merchant Performance (Y) & 0.875 & 0.7 & Reliable \\
\hline
\end{tabular}

Source: Processed Primary Data, 2018

\subsection{Descriptive Analysis}

Descriptive analysis is used to describe respondents' responses to each statement item which is categorized into 5 categories: Very Good, Good, Fairly Good, Not Good and Very Bad, with a maximum value of :5, minimum value: 1 , and interval distance: (maximum value-minimum value) $: 5=(5-1): 5=0.8$.

1. Based on respondents' responses obtained from 20 statements regarding management variables, it can be seen that the highest score is 3.03 and is included in the fairly good category, namely the statement regarding "routine waste is transported so that there is no accumulation" and the lowest score is 2, 40 and is included in the bad category, namely a statement regarding "there is a guarantee from fire and the collapse of the market building". From these data, the results obtained that the average management variable has a score above 2.70 and is included in the fairly good category. These results indicate that the majority of respondents consider that the management, empowerment, competitive strategy, and market physical conditions, which have been carried out by the manager, have been quite good.

2. Based on respondents' responses obtained from 16 statements regarding the market's physical condition variable, it can be seen that the highest score is 3.17 and is included in the fairly good category, namely the statement regarding "the road to the market is easy to reach", and the lowest score is 2.56 and is included in the bad category, namely a statement regarding the "availability of electrical facilities". From these data, the average result of the market physical condition variable is 2.75 and is included in the fairly good category. These results indicate that the majority of respondents think that the physical condition of the existing market is quite good.

3. Based on the respondents' responses obtained from the ten statements above regarding the competitive strategy variable, it can be seen that the highest score is 3.62 and is included in the good category, namely the statement regarding "traders have quality products" and "traders carry out product development" and the lowest score is 3.16 and is included in the fairly good category, namely a statement regarding "the products sold are reliable and trustworthy". From these data, the average result of the competitive strategy variable is 3.44 and is included in the good category. These results indicate that the majority of respondents consider that the competitive strategy that has been implemented has been good. 
4. Based on the respondents' responses obtained from six statements regarding the merchant's performance variable, it can be seen that the highest score is 3.58 and is included in the good category, namely the statement regarding "buyers who come are regular customers", and the lowest score is 3,33 and included in the fairly good category, namely the statement regarding "Buyers who come always increase every day". From these data, the average result of the trader's performance variable is 3.50 and is included in the good category. These results indicate that the majority of respondents considered that the performance of traders achieved was good.

5. Based on these results, for the partial effect value, it can be seen that the influence of management on the performance of traders is 0.304 or $30.4 \%$, the influence of empowerment on the performance of traders is 0.173 or $17.3 \%$, the influence of market physical conditions on performance traders by 0.284 or $28.4 \%$ and the influence of competitive strategy on the performance of traders by 0.247 or $24.7 \%$.

\subsection{Hypothesis Test Results}

The following are the results of partial hypothesis testing of each factor on the performance of traders.

Table 2

Effect of Each Variable on Y

\begin{tabular}{|c|c|c|c|c|c|c|}
\hline Variable & $\begin{array}{c}\text { Original } \\
\text { Sample (O) }\end{array}$ & $\begin{array}{c}\text { Sample } \\
\text { Mean (M) }\end{array}$ & $\begin{array}{l}\text { Standard } \\
\text { Deviation } \\
\text { (STDEV) }\end{array}$ & $\begin{array}{c}\text { Standard } \\
\text { Error } \\
\text { (STERR) }\end{array}$ & $\begin{array}{c}\text { TStatistics }_{\text {Sta }} \\
(|| \text { O/STERR }\end{array}$ & PValues \\
\hline Market Physical Conditions $\rightarrow$ Trader Performance & 0.284 & 0.284 & 0.073 & 0.073 & 3.878 & 0 \\
\hline Empowerment $\rightarrow$ Merchant Performance & 0.173 & 0.158 & 0.086 & 0.086 & 2.017 & 0.048 \\
\hline Management $\rightarrow$ Merchant Performance & 0.304 & 0.315 & 0.08 & 0.08 & 3.817 & 0 \\
\hline Competitive Strategy $\rightarrow$ Trader Performance & 0.247 & 0.254 & 0.053 & 0.053 & 4.689 & 0 \\
\hline
\end{tabular}

Source: Processed Primary Data, 2018

Based on Table 2, for the partial influence value, it can be seen that the influence of management on the performance of traders is 0.304 or $30.4 \%$, the influence of empowerment on the performance of traders is 0.173 or $17.3 \%$, the influence of market physical conditions on the performance of traders is 0.284 or $28.4 \%$ and the effect of competitive strategy on the performance of traders is 0.247 or $24.7 \%$. The model of the data analysis test results can be seen in Fig. 1 below

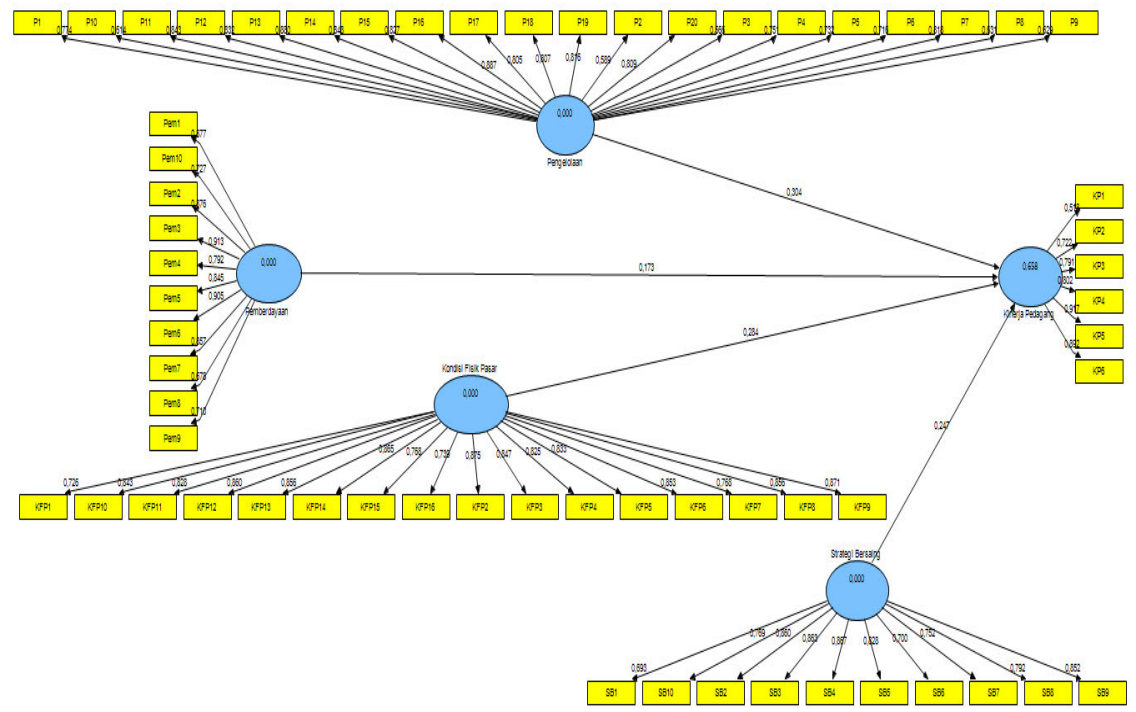

Fig. 1. Output PLS Algorithm

Table 3

Result of Direct Effect Test and Significance Test of X on Y

\begin{tabular}{|c|c|c|c|c|c|c|}
\hline Variable & $\begin{array}{l}\text { Original } \\
\text { Sample } \\
\text { (O) }\end{array}$ & $\begin{array}{l}\text { Standard } \\
\text { Deviation } \\
\text { (STDEV) }\end{array}$ & $\begin{array}{c}\text { T }_{\text {Statistics }} \\
(\mid \text { O/STERR } \mid)\end{array}$ & PValues & \multicolumn{2}{|c|}{ Conclusion } \\
\hline Market Physical Conditions $\rightarrow$ Trader Performance & 0.304 & 0.08 & 3.817 & 0.000 & Ho rejected & Sign. \\
\hline Empowerment $\rightarrow$ Merchant Performance & 0.173 & 0.086 & 2.017 & 0.048 & Ho rejected & Sign. \\
\hline Management $\rightarrow$ Merchant Performance & 0.284 & 0.073 & 3.878 & 0.000 & Ho rejected & Sign. \\
\hline Competitive Strategy $\rightarrow$ Trader Performance & 0.247 & 0.053 & 4.689 & 0.000 & Ho rejected & Sign. \\
\hline
\end{tabular}

Source: Processed Primary Data, 2018 
1. Based on the direct influence test and the management significance test on the performance of traders, it can be seen that the $t$-count value is 3.817 because the value is greater than 1.96 or $(3.817>1.96)$ and the significance value ( $p$-values) is significant at level $5 \%$ or 0.05 , it can be concluded that rejecting $\mathrm{H} 0$ and accepting Ha, which means that management has a significant influence on the performance of traders with a percentage of influence of $30.4 \%$. Thus, this study succeeded in proving the first hypothesis which states that management has a significant effect on traders' performance. This shows that the management of the Andir Market is good, the performance of traders will also be good. Recent literature states that the transportation of agricultural products in traditional markets has been much disrupted. This is exacerbated by the limited capacity of cold storage facilities in the product area, the risk of generating waste and losses in each supply chain which has a very high potential impact on the low profit and quality of food products, and the loss of (Yuanita, 2020; Kumar et al., 2021). Therefore, market managers must have adequate managerial skills and technical capabilities in the areas of planning, organizing, and monitoring markets. It is very important to apply Good Manufacturing (GMP) and Sanitation Standard Operating Procedures (SSOPS) as safety procedures and sanitation raw materials in the food supply chain (Tobing, 2015). Professional market management is expected to maintain market sustainability by increasing competitiveness against modern retail, providing a good level of service satisfaction, which in turn can contribute to regional income. The effectiveness of food supply chain management in traditional markets is very much needed to realize market management professionalism.

2. Based on the direct influence test and the empowerment significance test on the performance of traders, the t-count value is 2.017 , because the value is more than 1.96 or $(2.017>1.96)$ and the significance value (p-values) is significant at the level of $5 \%$ or 0.05 , it can be concluded that rejecting $\mathrm{H} 0$ and accepting Ha, which means market empowerment has a significant influence on the performance of traders with the percentage of influence is $17.3 \%$. In other words, this study succeeded in proving the second hypothesis which states that market empowerment has a significant effect on traders' performance. This shows good and well-ordered market conditions, the performance of traders will also be good. From the observations, it is known that empowerment of Andir market traders needs to be done by fostering traditional market managers and market traders, facilitating market traders to obtain business capital, helping to improve traditional market facilities and infrastructure, facilitating the formation of traders' forums or associations as a means of fighting for rights and interests. the merchants. Market empowerment takes advantage of the performance of traders as the main actors of sustainable governance in the food supply chain. In this case, market empowerment uses the Public-Private-Community Partnership (PPCP) approach, which is a synergistic operational model that aims to mutually benefit and provide the greatest benefit to the wider community. The study states that synergizing each element or related party is a must in the development and empowerment of traditional markets (Grabs \& Carodenuto, 2021). Sustainable market empowerment is a point of concern for the government to design an effective food supply chain coordination mechanism, taking into account the quality and return of products so that traditional markets can become a reference for local people to meet their daily needs (Zhang, Liu, \& Niu, 2020).

3. Based on the direct influence test and the significance test of physical condition on the performance of traders, the t-count value is 3.878 , because the value is more than 1.96 or $(3.878>1.96)$ and the significance value (p-values) is significant at the $5 \%$ level. or 0.05 , it can be concluded that rejecting $\mathrm{H} 0$ and accepting $\mathrm{Ha}$, which means that competitive strategy has a significant influence on the performance of traders with a percentage of influence of $28.4 \%$. In other words, this study succeeded in proving the fourth hypothesis which states that competitive strategy has a significant effect on traders' performance. This shows that the better the strategy carried out, the better the performance of traders. From the results of observations, the improvement of the physical condition of Andir Market can increase the attractiveness of the market, including by providing adequate supporting facilities such as parking lots, clean toilets, prayer rooms, and garbage dumps that are provided according to needs. Previous literature explains that the Andir traditional market plays an important role in driving the economy of the people of Bandung, apart from being the estuary of the people's products, the market also functions as a place to work which is very meaningful for the community (Paskarina et al., 2007). Therefore, to increase comfort in the market, it is necessary to replace broken tile floors, provide clean water and provide information boards to increase the number of buyers. Previous literature states that future food supply chains are encouraged to provide more realistic recommendations to achieve inclusive growth and equitable and sustainable development (Henriksson et al., 2017).

4. Based on the direct influence test and the significance test of competitive strategy on the performance of traders, it can be seen that the t-count value is 4.689 because the value is more than 1.96 or $(4.689>1.96)$ and the significance value (pvalues) is significant at level $5 \%$ or 0.05 , it can be concluded that rejecting H0 and accepting Ha, which means that competitive strategy has a significant influence on the performance of traders with the percentage of influence is $24.7 \%$. In other words, this study succeeded in proving the fourth hypothesis which states that competitive strategy has a significant effect on traders' performance. This shows that the better the strategy carried out, the better the performance of traders. To face competition both with modern markets and with fellow traders in the market, the supply chain actors of the Andir traditional market, especially farmers, logistics entrepreneurs, and shipping services need to adapt and have special strategies because of the reality faced today that modern markets exist more than traditional markets. traditional. The existence of the market depends on the food supply chain, the existence of sellers, and market consumers. Lack of 
fundamental resilience in maintaining the flexibility of the entire food supply chain can lead to losses and reduced longterm well-being (Chenarides et al., 2021). The competitive strategies that can be carried out are through support from government policies (Huang et al., 2021); improve product safety, risk management, and quality k (Kumar et al., 2021); and use of technology (Alfian et al., 2020; Zhu \& Krikke, 2020; Shahbazi \& Byun, 2021).

5. Effect of Simultaneous Management, Empowerment, Market Physical Condition, and Competitive Strategy on Trader Performance with an R-square value (coefficient of determination) of 0.658 , then simultaneously management, empowerment, physical market conditions, and competitive strategies affect the performance of traders by $65.8 \%$. This means that the changes that occur in the performance of traders can be explained by the changes that occur in management, empowerment, physical market conditions, and competitive strategies, while the remaining $34.2 \%$ is explained by factors other than these variables. From the analysis results, simultaneously the four performance factors of traders in the Andir market have a significant effect on the food supply chain network with an R-square value of $0.658(65.8 \%)$ with $t_{\text {count }}$ greater than 1.96 or $(3.817>1.96)$. This means that if the changes that occur are good in the performance of traders, the food supply chain network in the Andir traditional market will also be good, while the remaining 0.342 (34.2\%) is explained by factors other than these variables. Hong and Yang (2021) revealed that the development of the digital era 4.0 requires traditional markets to be able to attract the attention of visitors who are starting to switch to modern markets. The study states that the success of the food supply chain is highly dependent on strong and effective interactions between ingredient vendors, contract packaging providers, repackers, co-manufacturers, intermediary traders, and other suppliers who are involved in the supply chain (Tobing, 2015). Zahur, (2007) added that the importance of community involvement in partnerships between the government and the private sector must be adapted to technology, especially those that focus on public health problems by maintaining food quality carried out by traders at the Andir market. Communities will benefit by acquiring new skills, knowledge, and technologies (Skietrys et al., 2008). Andir traditional market is famous for its supply of fresh food such as fresh vegetables and fruits that come from farmers. This fresh food product is a special characteristic of food that is grown or produced from the countryside and then sent to the Andir market. Unlike other traditional markets, the traders are also partly farmers who sell their products directly to the market. Because the products are easily damaged, the role of technology is needed. Identification of the need for a food supply chain design in the Andir market based on the performance of traders consists of management, empowerment, physical condition, and strategy. The structure of the design is presented in the activities and behavior of traders, where traders are part of the Public-Private-Community Partnership. Unfortunately, previous literature found that traditional markets often fail because they do not have social aspects and only prioritize physical and economic arrangements (Febrianty, 2013; Widiastuti, Paturusi, \& Dwijendra, 2017; Ardhiansyah \& Mahendarto, 2020). Therefore, this study offers a supply chain network design by including these four factors to facilitate the government in making improvements in the future. The private sector can contribute to balanced inclusiveness between the chain of traders and consumers. Meanwhile, the community, including traders, will benefit by gaining new benefits, skills, knowledge, and technology due to empowerment and performance improvement. In the end, designing a food supply chain is actually an uncomplicated matter if it has found the right factors and implemented it with the right strategy. It's just that the implementation in the field is sometimes full of uncertainty, including the risk case for the food product itself, especially how the partnership relationship can be built properly. Therefore, it is hoped that with this discovery, through improving the performance of traders, traditional markets can support market sustainability and maintain the effectiveness of food supply chain management.

\section{Conclusion}

Based on the results of research and discussion that have been carried out, it can be concluded that management, empowerment, physical market conditions, and competitive strategies affect the performance of traders by $65.8 \%$. This means that if the changes that occur are good in the performance of traders, the food supply chain network in traditional markets will also be good, while the remaining $0.342(34.2 \%)$ is explained by factors other than these variables. More in the results of the study succeeded in proving the hypothesis that the four factors had a significant effect on the performance of traders. This shows that the four have the impact of increasing the performance of traders so that traders in Andir Market benefit by increasing turnover and profits from sales. The success of the food supply chain network that was built due to strong interactions within the Public-Private-Community Partnership, especially the performance of traders, was able to face challenges during and after the pandemic. This study is limited to four factors with the scope of the study only in one area. Future studies are advised to add other factors that have a significant relationship with the food supply chain with a wider population area to investigate their influence globally.

\section{Acknowledgements}

This work was supported by the Indonesia Endowment Fund for Education (Lembaga Pengelola Dana Pendidikan/ LPDP), Ministry of Finance of the Republic of Indonesia. 


\section{References}

Adnyana, I. B. P., Anwar, N., Soemitro, R. A. A., \& Utomo, C. (2015). Critical Success Factors of Public-Private-Community Partnership in Bali Tourism Infrastructure Development. Journal of Sustainable Development, 8(6). https://doi.org/10.5539/jsd.v8n6p208

Alfian, G., Syafrudin, M., Farooq, U., Ma'arif, M. R., Syaekhoni, M. A., Fitriyani, N. L., ... Rhee, J. (2020). Improving efficiency of RFID-based traceability system for perishable food by utilizing IoT sensors and machine learning model. Food Control, 110. https://doi.org/10.1016/j.foodcont.2019.107016

Ardhiansyah, N. N., \& Mahendarto, T. (2020). Revitalizing and Reimagining the Indonesian Traditional Market (Case Study : Salaman Traditional Market Indonesia). In IOP Conference Series: Earth and Environmental Science (Vol. 436). https://doi.org/10.1088/1755-1315/436/1/012010

Bangia, A., Diebold, F. X., Schuermann, T., \& Stroughair, J. D. (2001). Modeling Liquidity Risk, with Implications for Traditional Market Risk Measurement and Management. Risk Management: The State of the Art pp. Boston, MA.: Springer International Publishing. https://doi.org/10.1007/978-1-4615-0791-8_1

Basrowi, B., Utami, P., Ali, J., \& Salleh, M. S. (2021). Supply Chains In Indonesia Facing Virus Corona (COVID-19): Models Innovation And Obstacles Faced. Bina Bangsa International Journal of Business and Management, 1(1), 1-12. https://doi.org/10.46306/bbijbm.v1i1.1

Chenarides, L., Manfredo, M., \& Richards, T. J. (2021). COVID-19 and Food Supply Chains. Applied Economic Perspectives and Policy, 43(1), 270-279. https://doi.org/10.1002/aepp.13085

Febrianty, D. (2013). Model of Role Strengthening of Traditional Market Based on Social Capital in Indonesia : Study Case Beringharjo Market, Jogjakarta. Journal of Economics and Sustainable Development, 4(5), 115-125.

Grabs, J., \& Carodenuto, S. L. (2021). Traders as sustainability governance actors in global food supply chains: A research agenda. Business Strategy and the Environment, 30(2), 1314-1332. https://doi.org/10.1002/bse.2686

Henriksson, P. J. G., Tran, N., Mohan, C. V., Chan, C. Y., Rodriguez, U. P., Suri, S., ... Phillips, M. J. (2017). Indonesian aquaculture futures - Evaluating environmental and socioeconomic potentials and limitations. Journal of Cleaner Production, 162, 1482-1490. https://doi.org/10.1016/j.jclepro.2017.06.133

Hill, P. (1966). Notes on Traditional Market Authority and Market Periodicity in West Africa. The Journal of African History, 7(2), 295-311. https://doi.org/10.1017/S0021853700006332

Hong, S., \& Yang, J. (2021). An Empirical Study on Digital Transformation of Traditional Markets ; Focused on Traditional Market Delivery Application. Journal of the Korea Academia-Industrial Cooperation Society, 22(6), 484-491.

Huang, X., Yang, S., \& Wang, Z. (2021). Optimal pricing and replenishment policy for perishable food supply chain under inflation. Computers and Industrial Engineering, 158(August). https://doi.org/10.1016/j.cie.2021.107433

Jacobson, C., \& Ok, S. O. (2008). Success factors: Public works and public-private partnerships. International Journal of Public Sector Management, 21(6), 637-657. https://doi.org/10.1108/09513550810896514

Kaplow, L. (1982). The Accuracy of Traditional Market Power Analysis and a Direct Adjustment Alternative. Harvard Law Review, 95(8), 1817. https://doi.org/10.2307/1340650

Kolzow, D. R. (1994). Public/private partnership: The economic development organization of the 90s. Economic Development Review, 12(1).

Kumar, A., Mangla, S. K., Kumar, P., \& Song, M. (2021). Mitigate risks in perishable food supply chains: Learning from COVID-19. Technological Forecasting and Social Change, 166(May). https://doi.org/10.1016/j.techfore.2021.120643

Kurniawan, M., Lubis, M. M., \& Simanullang, E. S. (2020). Comparative Analysis of Consumer Shopping Behavior in Food Daily in Modern Market and Traditional Market (Case Study: Hypermart Modern Market and Tavip Traditional Market, Binjai City , North Sumatra). Agriuma, 2(1), 11-19.

Lambert, D. M., Cooper, M. C., \& Pagh, J. D. (1998). Supply chain management: implementation issues and research opportunities. The International Journal of Logistics Management, 9(2), 1-20. Retrieved from https://www.emeraldinsight.com/doi/pdf/10.1108/09574099810805807

Misırlısoy, D. (2020). Towards Sustainable Adaptive Reuse of Traditional Marketplaces. Historic Environment: Policy and Practice, 00(00), 1-17. https://doi.org/10.1080/17567505.2020.1784671

Mukhsin, M., \& Suryanto, T. (2021). The effect of supply agility mediation through the relationship between trust and commitment on supply chain performance. Uncertain Supply Chain Management, 9(3), 555-562. https://doi.org/10.5267/j.uscm.2021.6.006

Najib, M. F., \& Sosianika, A. (2017). Retail Service Quality in Indonesia: Traditional Market VS Modern Market. Academy of Marketing Studies Journal, 21(2), 2678.

Nelwan, J. W., \& Rumokoy, F. S. (2017). the Existence of Traditional Market Toward Modern Market in Tomohon City. Jurnal EMBA: Jurnal Riset Ekonomi, Manajemen, Bisnis Dan Akuntansi, 5(3), 3348-3355. https://doi.org/10.35794/emba.v5i3.17511

Paskarina, C., Mariana, D., \& Atmoko, T. (2007). Evaluasi Kebijakan Pengelolaan Pasar Di Kota Bandung. Lembaga Penelitian Universitas Padjadjaran, (258), 44. 
Rahadi, R. A. (2012). Factors Related to Repeat Consumption Behaviour: A Case Study in Traditional Market in Bandung and Surrounding Region. Procedia - Social and Behavioral Sciences, 36(June 2011), 529-539. https://doi.org/10.1016/j.sbspro.2012.03.058

Shahbazi, Z., \& Byun, Y. C. (2021). A procedure for tracing supply chains for perishable food based on blockchain, machine learning and fuzzy logic. Electronics (Switzerland), 10(1), 1-21. https://doi.org/10.3390/electronics10010041

Skietrys, E., Raipa, A., \& Bartkus, E. V. (2008). Dimensions of the efficiency of public - Private partnership. Engineering Economics, 3(58), 45-50. https://doi.org/10.5755/j01.ee.58.3.11542

Tobing, B. (2015). Rantai Pasok Pangan (Food Supply chain). Supply Chain Indonesia, pp. 1-8. Retrieved from https://supplychainindonesia.com/rantai-pasok-pangan-food-supply-chain/

Wang, H., Ko, E., Woodside, A., \& Yu, J. (2021). SNS marketing activities as a sustainable competitive advantage and traditional market equity. Journal of Business Research, 130(August 2019), 378-383. https://doi.org/10.1016/j.jbusres.2020.06.005

Widiastuti, W., Paturusi, S. A., \& Dwijendra, N. K. A. (2017). Cultural Value Transformation in Traditional Market Spatial Planning in City of Denpasar, Gianyar and Klungkung - Bali, Indonesia. Journal of Sustainable Development, $10(4), 97$. https://doi.org/10.5539/jsd.v10n4p97

Yuanita, D. (2020). Memperkuat Rantai Pasok Pangan. Retrieved August 6, 2021, from https://news.detik.com/kolom/d5066280/memperkuat-rantai-pasok-pangan

Zahur, M. (2007). Solid Waste Management of Dhaka City: Public Private Community Partnership. BRAC University Journal, 4(2), 93-97.

Zhang, Z., Liu, S., \& Niu, B. (2020). Coordination mechanism of dual-channel closed-loop supply chains considering product quality and return. Journal of Cleaner Production, 248, 119273. https://doi.org/10.1016/j.jclepro.2019.119273

Zhu, Q., \& Krikke, H. (2020). Managing a sustainable and resilient Perishable Food Supply Chain (PFSC) after an outbreak. Sustainability (Switzerland), 12(12), 1-11. https://doi.org/10.3390/su12125004

Zuurbier, P. J. P. (1996). Market structure and vertical co-ordination. In Proc. 2nd Int. Conf. on Chain management in agriand foodbusiness, JH Trienekens, PJP Zuurbier (eds.) (pp. 307-325). Netherlands: Dept. Management Studies, Agric. Univ. Wageningen. 
(C) 2021 by the authors; licensee Growing Science, Canada. This is an open access article distributed under the terms and conditions of the Creative Commons Attribution (CCBY) license (http://creativecommons.org/licenses/by/4.0/). 